\title{
Liquefaction potential of sands at the Krško-Brežice field, Slovenia
}

\author{
Jasna Smolar*, Matej Maček and Ana Petkovšek \\ University of Ljubljana, Faculty of Civil and Geodetic Engineering, Jamova cesta 2, 1000 Ljubljana, Slovenia; ("corresponding author: jasna.smolar@fgg.uni-lj.si*; \\ matej.macek@fgg.uni-lj.si; ana.petkovsek@fgg.uni-lj.si)
}

doi: $10.4154 / g c .2019 .12$

\section{Article history: \\ Manuscript received December 02, 2018 Revised manuscript accepted March 07, 2019 Available online May 31, 2019}

\begin{abstract}
The Krško-Brežice field is one of the most seismically active areas in Slovenia. The most damaging recorded earthquake with an intensity of VIII (EMS) occurred on $29^{\text {th }}$ January 1917. It caused damage and claimed two lives. In the last 100 years, 9 earthquakes with intensity higher than VI (EMS) have been recorded.

At the investigated area, a top layer up to $5 \mathrm{~m}$ thick, consisting of recent deposit of very loose silts and sands (ML, SM, SP), covers the medium dense to dense Quaternary gravel, beneath which there are over-consolidated, uncemented Miocene silts and marls. The top layer could be prone to liquefaction, as reported for the close surroundings of Brežice, where the liquefaction phenomenon was observed during the Zagreb earthquake in 1880 and during the Kupa Valley earthquake in 1909.

The paper presents the results of laboratory index tests, cyclic simple shear tests and field investigations (SPT, CPT, (S)DMT, $v_{\mathrm{s}}$ measurements), which were carried out to assess the liquefaction potential of the top layer at the location of the Brežice Hydroelectric Power Plant (HPP). All results show that the top layer is prone to liquefaction for an earthquake with a 475 year return period. Cyclic simple shear test results show that the liquefaction potential of horizontal ground for an earthquake with a 475 year return period can be reduced by the densification of the top layer to at least $95 \%$ of maximum Proctor density.
\end{abstract}

Keywords: earthquake, CSR, liquefaction potential, silty sand, laboratory investigations, field tests ground acceleration, $a_{\max }$, magnitude, $M$ ) and soil properties (e.g. liquid limit, $w_{\mathrm{L}}$, plasticity index, $I_{\mathrm{P}}$, density, $\rho$, grain size distribution, number of cycles to liquefaction, $N$, cyclic resistance ratio, $C R R)$. The liquefaction potential of soils can be assessed from different laboratory and field investigations by several liquefaction susceptibility criteria, mostly developed for sands (POLITO \& MARTIN, 2001, YOUD et al., 2001, ANDRUS et al., 2004, BOULANGER \& IDRISS, 2016, 2006, IDRISS \& BOULANGER, 2006, MARCHETTI \& MARCHETTI, 2016, among others).

This paper presents the assessment of liquefaction potential of the top layer at the location of the Brežice HPP, based on laboratory index and cyclic simple shear tests, as well as field cone penetration tests (CPT/CPTu), standard penetration tests (SPT), flat (seismic) dilatometer tests ((S)DMT) and shear wave velocity measurements $\left(v_{\mathrm{s}}\right)$.

\section{STUDY AREA}

\subsection{Geological and hydrological setting}

The top layer at the location (Fig. 1) is up to $5 \mathrm{~m}$ thick and consists of loose alluvial silty sands and contains fine coal particles that originate from the flotation processes from the area around $60 \mathrm{~km}$ upstream, where the coal mines have operated for the last 300 years. Poplar tree roots appear up to $4 \mathrm{~m}$ depth and prove the development of the "palaeo" ground during large flood events (PETKOVŠEK et al., 2017).

Beneath the top layer, the medium dense to dense Quaternary gravels classified as silty sandy gravel (GM) to poorly graded gravel (GP) are deposited in thicknesses of between
Factors governing liquefaction may be grouped into a geological profile, consisting of seismicity at the location (e.g. peak 


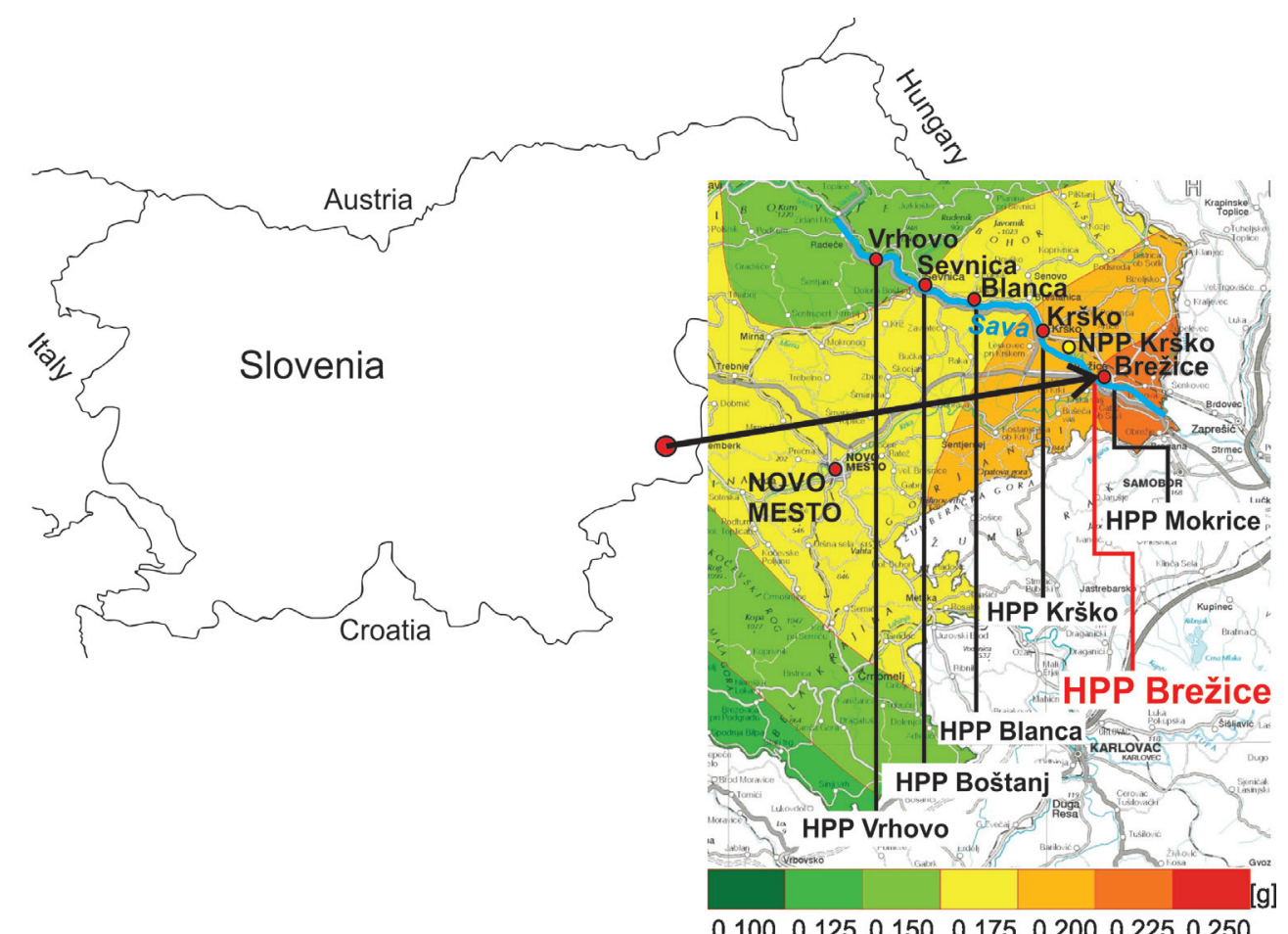

Figure 1. Location of the Brežice HPP - the investigated area in the chain of the lower Sava river Hydroelectric Power plants and the Krško Nuclear Power Plant (NPP). Different colours represent design ground accelerations in rock or firm soil (ARSO, 2001).

8 and $12 \mathrm{~m}$. The bedrock consists of over-consolidated, uncemented Miocene silt and marl, with some inclusions of weak, soft limestone.
The ground water level ranges from 4 - 6 m below the ground surface and follows the water level fluctuation in the Sava River, which frequently floods the area. During floods, the water level

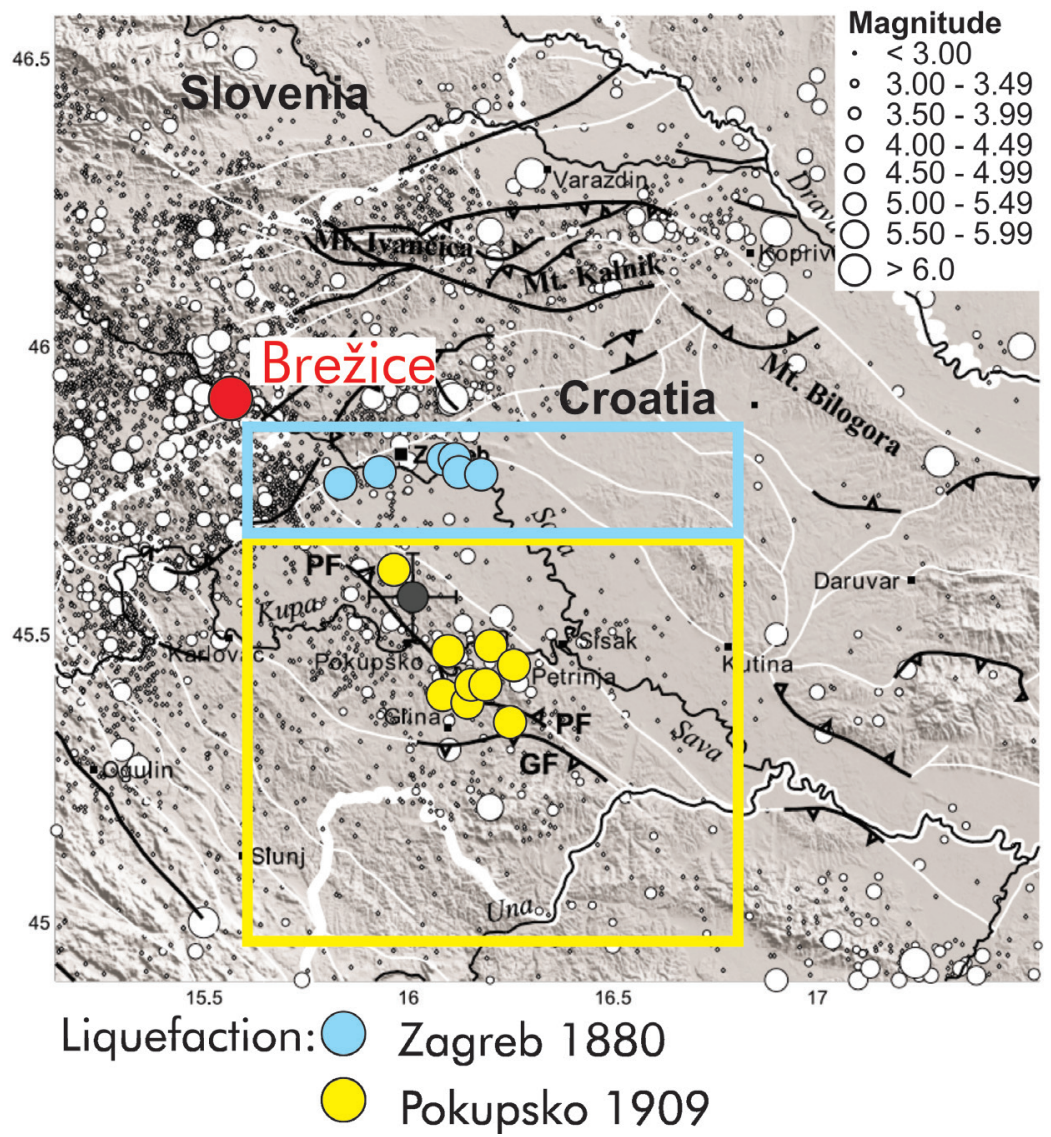

Figure 2. Epicentres of earthquakes at the Krško-Brežice field and in its close surroundings from 567 to $2007 \mathrm{AD}$, and the locations where liquefaction-related effects were observed during the Zagreb (blue dots) and Kupa Valley (yellow dots) earthquakes (VEINOVIĆ et al., 2007, HERAK et al., 2009, HERAK \& HERAK, 2010). 
Table 1. Design ground accelerations at the location of the Brežice HPP.

\begin{tabular}{|c|c|c|c|c|}
\hline \multirow{2}{*}{ method } & \multirow{2}{*}{ return period } & \multirow{2}{*}{ magnitude } & \multicolumn{2}{|c|}{ design ground acceleration } \\
\hline & & & rock or firm soil & loose silt, sand \\
\hline \multirow{2}{*}{ Slovenian national probabilistic seismic hazard analysis (ARSO, 2001) } & 475 & - & $0.225 \mathrm{~g}$ & - \\
\hline & 1000 & - & $0.250 \mathrm{~g}$ & - \\
\hline \multirow{3}{*}{ detailed probabilistic seismic hazard analysis (ALEKSOVSKI et al., 2008) } & 200 & 5.6 & $0.230 \mathrm{~g}$ & $0.290 \mathrm{~g}$ \\
\hline & 475 & 5.8 & $0.280 \mathrm{~g}$ & $0.350 \mathrm{~g}$ \\
\hline & 1000 & 6.25 & $0.295 \mathrm{~g}$ & $0.370 \mathrm{~g}$ \\
\hline SHARE model (LAl et al., 2017) & 475 & - & $0.320 \mathrm{~g}$ & - \\
\hline
\end{tabular}
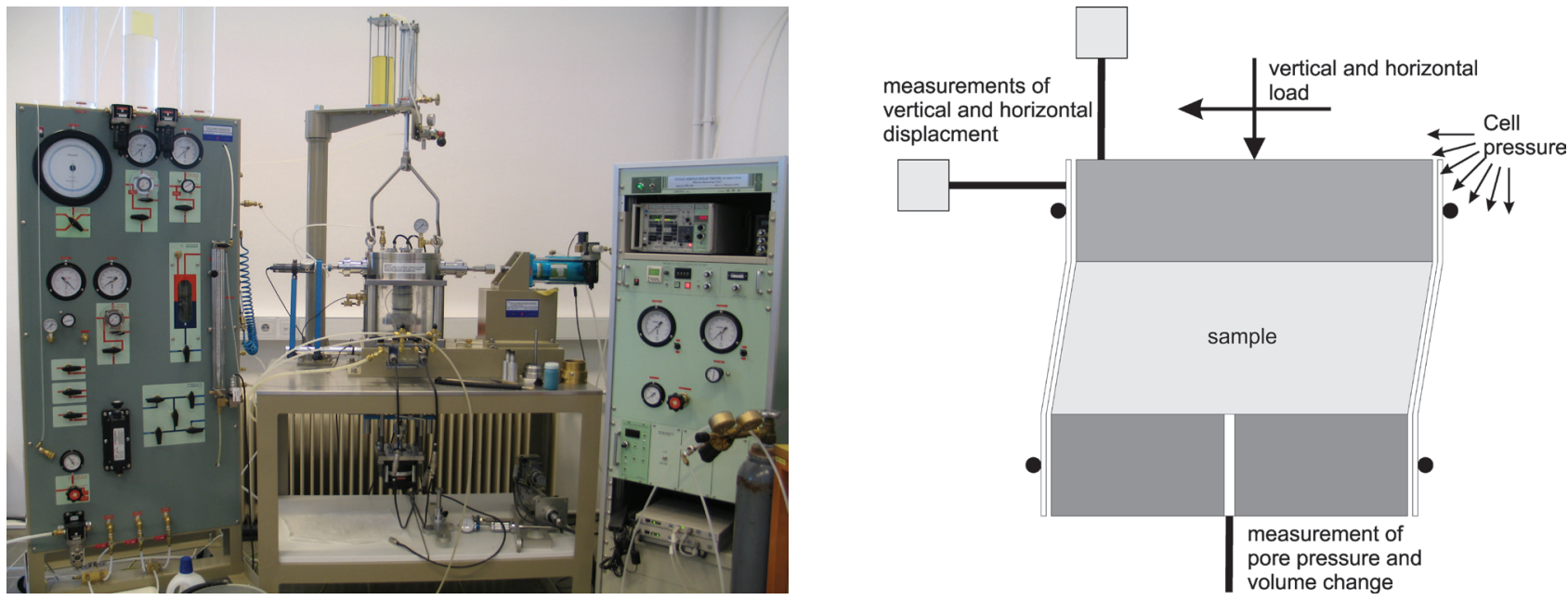

Figure 3. Cyclic simple shear apparatus (left) and schematic illustration of the investigation (right).

rises above the ground surface and may remain for days (PETKOVŠEK et al., 2017). Inside the influential area of the Brežice HPP, the groundwater regime has been changed due to the operation of the HPP Brežice.

\subsection{Seismicity}

Figure 2 shows the epicentres and magnitudes of earthquakes at the Krško-Brežice field and in its close surroundings from 567 to 2007 AD. Blue and yellow symbols represent locations in Croatia where liquefaction was observed during the Zagreb (1880) and Kupa Valley (1909) earthquakes (after VEINOVIĆ et al., 2007 and HERAK \& HERAK, 2010).

The design ground acceleration at the location (Table 1) was predicted based on three different methodologies: (1) currently valid Slovenian national probabilistic seismic hazard analysis (Fig. 1) (ARSO, 2001), (2) detailed probabilistic seismic hazard analysis at the location of the HPP Brežice (ALEKSOVSKI et al., 2008) and (3) recent Seismic hazard harmonization in Europe - SHARE model (LAI et al., 2017).

\subsection{Earthquake induced Cyclic Stress Ratio (CSR)}

CSR can be estimated using eq. 1, developed as part of the Simplified Liquefaction Procedure (BOULANGER \& IDRISS, 2014):

$$
\operatorname{CSR}_{M, \sigma_{v}^{\prime}}=0.65 \cdot \frac{\sigma_{v}}{\sigma_{v}^{\prime}} \cdot \frac{a_{\max }}{g} \cdot r_{d}
$$

where $a_{\max }$ is the peak ground surface acceleration, $g$ the acceleration of gravity, $\sigma_{v}$ the total vertical stress at depth $z, \sigma_{v}^{\prime}$ the effective vertical stress at depth $z$ and $r_{d}$ shear stress reduction factor that accounts for the dynamic response of the soil profile.
Based on IDRISS (1999), parameter $r_{d}$ could be calculated using eq. 2.

$$
\begin{gathered}
r_{d}=\exp [\alpha(z)+\beta(z) \cdot M] \\
\alpha(z)=-1.012-1.126 \cdot \sin \left(\frac{z}{11.73}+5.133\right) \\
\beta(z)=0.106+0.118 \cdot \sin \left(\frac{z}{11.28}+5.142\right)
\end{gathered}
$$

where $z(\mathrm{~m})$ is the depth below the ground surface, $M$ moment magnitude and the arguments inside the sin terms are in radians.

The case history CSR values adjusted to a reference magnitude $M=7.5$ and $\sigma_{v}^{\prime}=1 \mathrm{~atm}=101 \mathrm{kPa}$ could be calculated using eq. 5 and eq. 6 (BOULANGER \& IDRISS, 2014).

$$
\begin{gathered}
\operatorname{CSR}_{M=7.5, \sigma_{v}^{\prime}=1}=\frac{C S R_{M, \sigma_{v}^{\prime}}}{M S F \cdot K_{\sigma}} \\
M S F=6.9 \cdot \exp \left(\frac{-M}{4}\right)-0.058 \leq 1.8
\end{gathered}
$$

where $K_{\sigma} \approx 1$.

$\operatorname{CSR}_{M=7.5, \sigma_{v}=1}$ varies with depth. In this study it is evaluated for depths between $0.5 \mathrm{~m}$ and $4.0 \mathrm{~m}$, for an earthquake with a 475 year return period, design ground acceleration of $0.350 \mathrm{~g}$ (Table 1 , loose silt, sand) and GW level of $0.1 \mathrm{~m}$. Using parameters listed above, $C S R_{M=7.5, \sigma_{v}^{\prime}=1}$ is between 0.30 and 0.35 .

\section{EXPERIMENTAL METHODS}

Preliminary assessment of the top layer liquefaction potential was carried out based on its grain size distribution (SIST-TS CEN 
Table 2. Index properties of three samples from the top layer (adapted after PETKOVŠEK et al., 2017).

\begin{tabular}{|c|c|c|c|c|}
\hline Parameter & Test Method & sample 1 & sample 2 & sample 3 \\
\hline USCS Classification & ASTM D2487-10 & $\mathrm{ML} / \mathrm{CL}$ & SC & SM \\
\hline Natural water content, $w_{0}(\%)$ & SIST-TS CEN ISO/TS 17892-1 & 5.06 & 16.3 & 21.5 \\
\hline Natural density, $\rho\left(\mathrm{t} / \mathrm{m}^{3}\right)$ & SIST-TS CEN ISO/TS 17892-2 & 1.30 & 1.28 & 1.23 \\
\hline Dry density, $\rho_{\mathrm{d}}\left(\mathrm{t} / \mathrm{m}^{3}\right)$ & SIST-TS CEN ISO/TS 17892-2 & 1.23 & 1.10 & 1.01 \\
\hline Void ratio, natural state, $\mathrm{e}_{0}(-)$ & - & 1.15 & 1.53 & 1.61 \\
\hline Particle density, $\rho_{\mathrm{s}}\left(\mathrm{t} / \mathrm{m}^{3}\right)$ & SIST-TS CEN ISO/TS 17892-3 & 2.64 & 2.78 & 2.64 \\
\hline Liquid limit, $w_{\mathrm{L}}(\%)$ & SIST-TS CEN ISO/TS 17892-12 & 30 & $24-26$ & 39 \\
\hline Plasticity index, $I_{P}(\%)$ & SIST-TS CEN ISO/TS 17892-12 & 9 & $6-7$ & - \\
\hline Optimum water content, $\mathrm{SPCT}^{*}, w_{\mathrm{opt}}(\%)$ & DIN 18127 & 17.4 & 15.0 & 27.5 \\
\hline Maximum dry density, $\mathrm{SPCT}^{*}, \rho_{\mathrm{dmax}}\left(\mathrm{t} / \mathrm{m}^{3}\right)$ & DIN 18127 & 1.65 & 1.77 & 1.34 \\
\hline
\end{tabular}

DIN 18127

*SPCT - Standard Proctor compaction test

ISO/TS 17892-4) and Atterberg limits (SIST-TS CEN ISO/TS 17892-12).

The laboratory cyclic simple shear apparatus (Fig. 3, left), developed by Seiken Inc., was used to study the liquefaction potential of the top layer at natural void ratio and to evaluate the densification impact on the liquefaction potential mitigation. A procedure similar to that described by DAS (1992) was used. Tests were performed on top layer specimens statically compacted at their optimal water content into a mould with a diameter of $70 \mathrm{~mm}$ and height of $30 \mathrm{~mm}$ to the desired density (void ratio), and on intact specimens from top layer. The specimens were sheathed in a protective latex membrane without reinforcement.

Saturation was achieved by using the $\mathrm{CO}_{2}$, water, and axis translation technique. The saturation was successfully completed when the Skempton parameter B was higher than 0.95. After saturation, the specimens were isotropically consolidated at $75 \mathrm{kPa}$ of effective stress. The specimens were loaded with horizontal sinusoidal load at $0.5 \mathrm{~Hz}$ at desired cyclic stress ratio in undrained conditions (Fig. 3, right). The beginning of liquefaction was defined when the increase of pore water pressure was equal to $95 \%$ of effective vertical stress before cyclic loading.

Liquefaction potential of the top layer was evaluated also based on the results of in-situ Standard penetration tests (SPT)
(SIST EN ISO 22476-3), Cone penetration tests (CPT/CPTu) (SIST EN ISO 22476-1), Flat dilatometer tests (DMT) (SIST-TS CEN ISO/TS 22476-11) and shear wave velocity measurements $\left(v_{\mathrm{s}}\right)$. SPT and CPT are generally preferred for the evaluation of liquefaction potential because of the more extensive database and experience (YOUD et al., 2001). While the preferred SPT and $\mathrm{CPT}$ are recommended only for non-gravel soils, $v_{\mathrm{S}}$ measurements are appropriate for all soil types (ANDRUS et al., 2004).

\section{RESULTS AND DISCUSSION}

\subsection{Index properties - preliminary assessment of liquefaction potential}

Table 2 presents the index geotechnical properties of representative top layer specimens, and Fig. 4 (grey curves) shows the grain size distribution curves of all the investigated specimens. The grain size distribution of the top layer is not uniform and may vary from sandy silt to poorly graded sand. After ISHIHARA et al. (1980), the top layer belongs to the group of potentially liquefiable to most liquefiable soils. In comparison with the investigated samples, poorly graded sands from Nova loza and Moj dvor, where liquefaction appeared in 1880, belong to the group of most liquefiable soils (VEINOVIĆ et al., 2007). The Toyoura

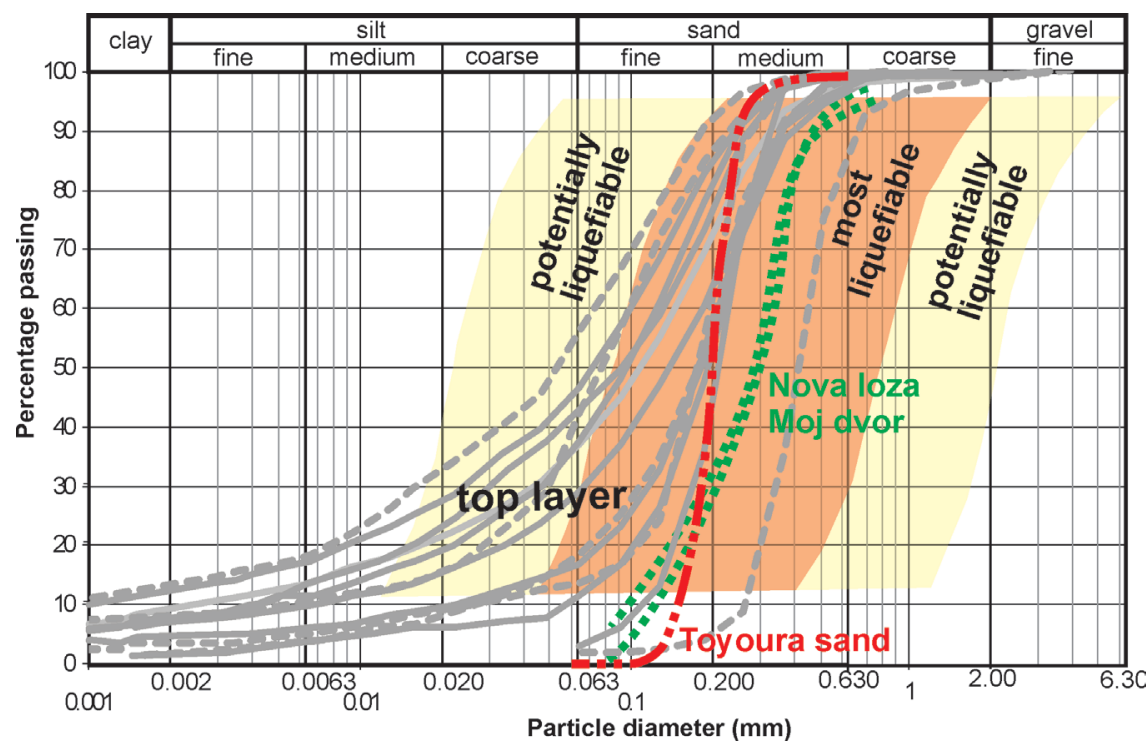

Figure 4. Grain size distribution of the top layer from the test site (grey curves). Grain size distribution curves for Toyoura sand, Nova loza and Moj dvor are reproduced from HOSONO \& YOSHIMINE (2004) and VEINOVIĆ et al. (2007), while boundaries for potentially liquefiable and most liquefiable soils are reproduced from ISHIHARA et al. (1980). 


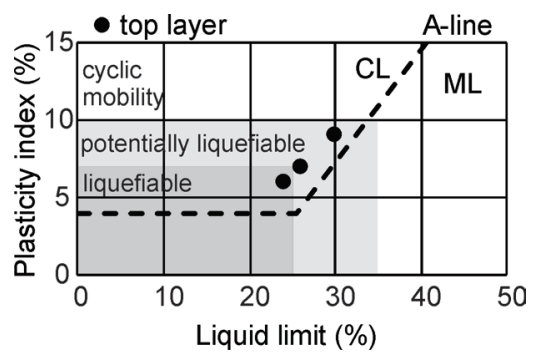

Figure 5. Assessment of the liquefaction potential based on plasticity liquefac tion criteria proposed by POLITO (2001).

sand also belongs to the same group, and was in the past widely used as reference material for the study of liquefaction. Using plasticity liquefaction criteria proposed by POLITO (2001), the top layer also belongs to the group of potentially liquefiable to liquefiable soils (Fig. 5).

\subsection{Laboratory cyclic simple shear tests}

Figure 6 shows the results of cyclic simple shear tests as a link between the induced cyclic stress ratio (CSR) and measured number of cycles to liquefaction. The tests were carried out on intact specimens and specimens prepared at different degrees of compaction $\left(D_{\mathrm{pr}}\right)$, expressed as the ratio between achieved dry density and maximum SPCT dry density given in Table 2.

$C S R_{M=7.5, \sigma^{\prime}=1}$ at the investigated area is about 0.30 (Fig. 6, horizontal solid grey line), while the corresponding equivalent number of stress cycles to liquefaction $(N)$, determined after KRAMER (1996), for an earthquake with a magnitude of 7.5 is about 15 (Fig. 6, vertical solid grey line).

Results of the laboratory cyclic simple shear tests confirm that the intact top layer is prone to liquefaction for an earthquake with a 475 year return period. Results obtained on intact top layer specimens are comparable with those for the Toyoura sand (HOSONO \& YOSHIMINE, 2004). Mechanically improved specimens compacted to at least $95 \%$ of maximum Proctor dry density (Table 2) will very probably resist the 475 year return period earthquake, although high excess pore pressure would be generated.

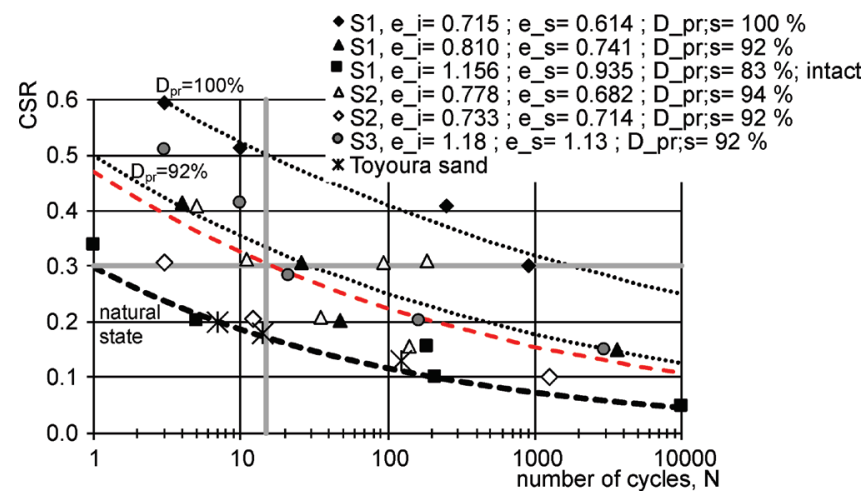

Figure 6. Results of cyclic simple shear tests. Data for the Toyoura sand were summarized after HOSONO \& YOSHIMINE (2004). Key: S1, S2, S3 - sample 1, sample 2 and sample 3, e_i - initial void ratio (at preparation of the specimen), e_s - void ratio prior to cyclic loading (after consolidation), D_pr;s - the ratio between specimens' dry density prior to cyclic loading and maximum SPCT dry density, red curve - assessed boundary between conditions where liquefaction is expected (below curve) and where resistant to liquefaction is sufficient (above curve).
These findings are valid for the horizontal ground without surface loading and with the GW level at the foundation ground (e.g. $0.1 \mathrm{~m}$ below ground surface).

\subsection{Standard penetration tests (SPT)}

Figure 7 (red symbols) shows $\left(N_{1}\right)_{60}$ values calculated from SPT measurements in the top layer at the location of the Brežice HPP, in comparison with SPT based liquefaction case history data, including soils with different contents of fines (IDRISS \& BOULANGER, 2010). Recommended deterministic SPT based triggering correlations (boundary curves) for cohesionless soils having various amounts of fines (FC), presented in Fig. 7, are summarized after IDRISS \& BOULANGER (2006).

Results of SPT confirm that the top layer is prone to liquefaction for an earthquake with a 475 year return period.

\subsection{Cone penetration tests (CPT/CPTu)}

Figure 8 shows the $q_{\mathrm{clN}}$ values calculated from CPT measurements in the top layer at the location of the Brežice HPP in comparison with CPT based liquefaction case history data, including soils with different contents of fines (BOULANGER \& IDRISS, 2014). Recommended deterministic CPT based triggering correlations (boundary curves) for clean sands and for cohesionless soils with various amounts of fines (FC) presented in Fig. 8 are summarized after BOULANGER \& IDRISS (2014).

Results of CPT also confirm that the top layer is prone to liquefaction for an earthquake with a 475 year return period.

\subsection{Flat dilatometer tests (DMT)}

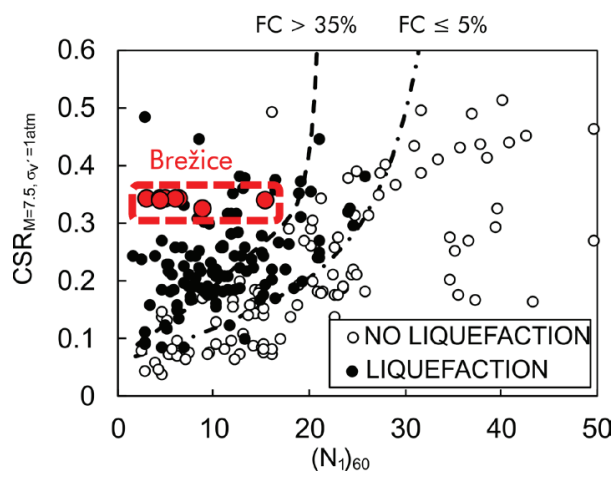

Figure 7. SPT - based soil liquefaction potential assessment with the case history data and recommended boundary curves for soils with different fines contents $(F C)$. $\left(N_{1}\right)_{60}$ - corrected SPT N value for $60 \%$ energy efficiency and overburden pressure of $1 \mathrm{~atm}$.

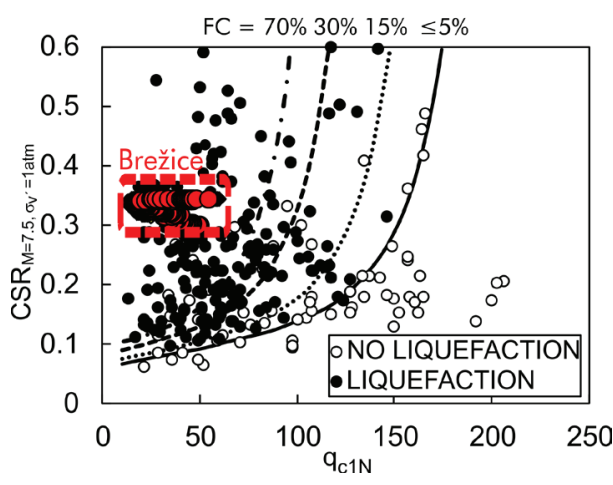

Figure 8. CPT - based soil liquefaction potential assessment with the case history data and recommended boundary curves for soils with different fines content $(\mathrm{FC}) . q_{\mathrm{c} 1 \mathrm{~N}}-$ normalized cone tip resistance. 


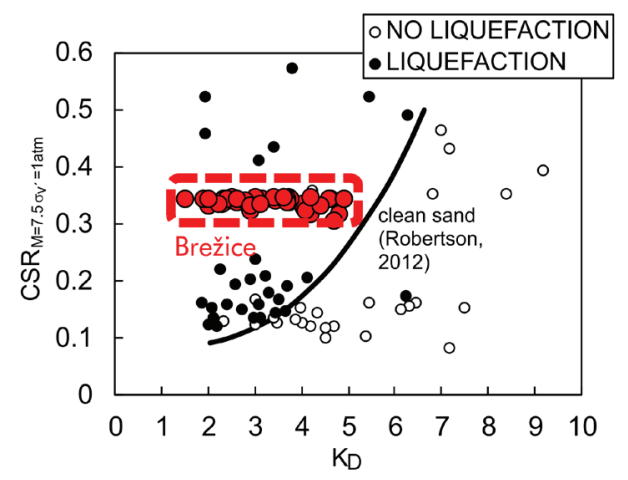

Figure 9. DMT - based soil liquefaction potential assessment with the case history data and recommended boundary curve for clean sand. $K_{D}$ - horizontal stress index.

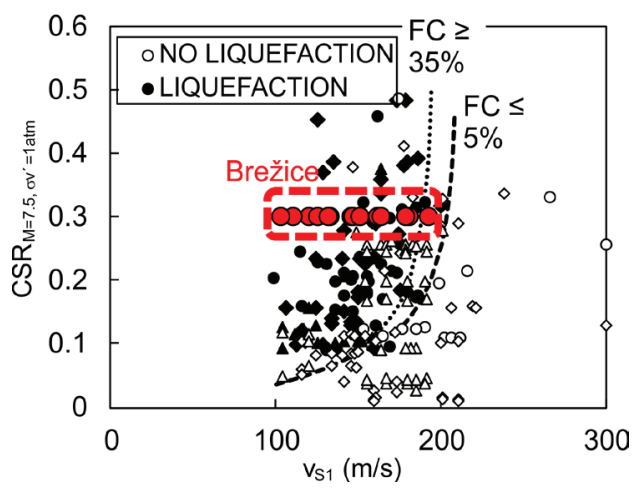

Figure 10. Liquefaction resistance curves proposed by ANDRUS \& STOKOE (2000) with case history data and calculated values for the top layer at the location of the HPP Brežice. $v_{s 1}$ - stress-corrected shear-wave velocity.

Figure 9 shows the $K_{D}$ measured values using DMT in the top layer at the location of the HPP Brežice in comparison with DMT- $K_{\mathrm{D}}$ based liquefaction case history data for silty sand and sandy silt, regardless of the fines content (MARCHETTI \& MARCHETTI, 2016, ROLLINS \& REMUND, 2016). Recommended deterministic DMT based triggering correlation (boundary curve) for clean sand presented in Fig. 9 is summarized after ROBERTSON (2012).

Results of DMT also show that the top layer is prone to liquefaction for an earthquake with a 475 year return period.

\subsection{Shear wave velocity measurements $\left(v_{s}\right)$}

Figure 10 shows the $v_{\mathrm{s} 1}$ values calculated from shear wave velocity measurements in the top layer at the location of the Brežice HPP in comparison with liquefaction resistance curves proposed by ANDRUS \& STOKOE (2000) and case history data (ANDRUS et al., 2004).

Shear wave velocity measurements also confirm that the top layer is prone to liquefaction for an earthquake with a 475 year return period.

\section{CONCLUSIONS}

The liquefaction potential of the top layer at the Krško-Brežice field was assessed using laboratory and field tests. Results were compared with case history data and recommended boundary liquefaction curves and were evaluated using liquefaction susceptibility criteria proposed by different authors.
It was observed that there are no significant differences in the evaluation of liquefaction potential based on the various test methods. The analyses indicate that there is a clear threat of liquefaction in the top layer, assuming a water table $0.1 \mathrm{~m}$ below the ground surface for an earthquake with a 475 year return period. Thus, for liquefaction potential mitigation, the sites require ground improvement (densification).

The efficiency of in-situ mechanical improvement for the liquefaction potential mitigation of the top layer was investigated in the scope of the design of the Brežice HPP, using three different techniques: Vibratory Roller Compaction, Rapid Impact Compaction (RIC) and Soil Mixing. The efficiency of each technique was analysed in PETKOVŠEK et al. (2017) and VUKADIN (2013).

\section{ACKNOWLEDGEMENT}

This work was funded by the HESS and European Union's Horizon 2020 research and innovation programme under grant agreement No. 700748 and realised in close cooperation with IRGO Ljubljana and SLP Ljubljana. The authors would like to express special thanks to Mr. B.Sc. Andrej UNETIČ (HSE Invest) for his help at realising the investigation program and to many engineers and technicians for their vital field work and data collection.

\section{REFERENCES}

ALEKSOVSKI, D., MIRAKOVSKI, G., DOJČINOVSKI, D., ŠEŠOV, V., EDIP, K., ZAFIROVA I., GADJA, V. \& GJORGJESKA, I. (2008): HE Brežice Geofizikalne raziskave in seizmična mikrorajonizacija.- IZIIS univerze Sv. Kiril I Metodij, Skopje.

ANDRUS, R.D. \& STOKOE, K.H. (2000): Liquefaction Resistance of Soils from Shear-Wave Velocity.- Journal of Geotechnical and Geoenvironmental Engineering, 126, 1015-1025. doi: 10.1061/(ASCE)1090-0241(2000)126:11(1015)

ANDRUS, R.D., STOKOE, K.H. \& HSEIN JUANG, C. (2004): Guide for ShearWave-Based Liquefaction Potential Evaluation. Earthq.- Spectra 20, 285-308. doi: 10.1193/1.1715106

ARSO (2001): Slovenian Environment Agency. http://www.arso.gov.si/potresi/podatki/ projektni_pospesek_tal.html (accessed: 29.11.2018).

ASTM D2487-10 (2010): Standard Practice for Classification of Soils for Engineering Purposes (Unified Soil Classification System).- ASTM International, West Conshohocken, PA, 2010

BOULANGER, R. \& IDRISS, I. (2014): CPT and SPT based liquefaction triggering procedures.- Rep No UCDCGM-14 1.

BOULANGER, R.W. \& IDRISS, I.M. (2016): CPT-Based Liquefaction Triggering Procedure.- J. Geotech. Geoenvironmental Eng., 142. doi: 10.1061/(ASCE) GT.1943-5606.0001388

BOULANGER, R.W. \& IDRISS, I.M. (2006): Liquefaction Susceptibility Criteria for Silts and Clays.- J. Geotech. Geoenvironmental Eng., 132, 1413-1426. doi: 10.1061/(ASCE)1090-0241(2006)132:11(1413)

BRAY, J.D., SANCIO, R.B., DURGUNOGLU, T., ONALP, A., YOUD, T.L., STEWART, J.P., SEED, R.B., CETIN, O.K., BOL, E., BATURAY, M.B., CHRISTENSEN, C. \& KARADAYILAR, T. (2004): Subsurface Characterization at Ground Failure Sites in Adapazari, Turkey.- J. Geotech. Geoenvironmental Eng., 130, 673-685. doi: 10.1061/(ASCE)1090-0241(2004)130:7(673)

CHU, D.B., STEWART, J.P., LEE, S., TSAI, J.S., LIN, P.S., CHU, B.L., SEED, R.B., HSU, S.C., YU, M.S. \& WANG, M.C.H. (2004): Documentation of soil conditions at liquefaction and non-liquefaction sites from 1999 Chi-Chi (Taiwan) earthquake.- Soil Dyn. Earthq. Eng., 24, 647-657. doi: 10.1016/j.soildyn.2004.06.005

CUBRINOVSKI, M., RHODES, A., DE LA TORRE, C., BRAY, J. \& NTRITSOS, N. (2018): Liquefaction Hazards from "Inherited Vulnerabilities."- ce/papers 2, 39-54. doi: 10.1002/cepa.661

DAS, B.M. (1992): Principles of Soil Dynamics, 1st edition.- Thomson-Engineering. DIN 18127 (2012): Soil, investigation and testing - Proctor-test.

HERAK, D., HERAK, M. \& TOMLJENOVIĆ, B. (2009): Seismicity and earthquake focal mechanisms in North-Western Croatia.- Tectonophysics, 465, 212-220. doi: 10.1016/j.tecto.2008.12.005

HERAK, D. \& HERAK, M. (2010) The Kupa Valley (Croatia) Earthquake of 8 October 1909-100 Years Later.- Seismol. Res. Lett., 81, 30. doi: 10.1785/gssrl.81.1.30

HOSONO, Y. \& YOSHIMINE, M. (2004): Liquefaction of sand in simple shear condition. In Proceedings of the International Conference on Cyclic Behaviour of Soils and Liquefaction Phenomena, Bochum, Germany, 31 March - 02 April 2004. A.A. Balkema, Rotterdam: 129-136 doi: 10.1201/9781439833452.ch16 
IDRISS, I.M. (1999): An update to the Seed-Idriss simplified procedure for evaluating liquefaction potential, in Proceedings, TRB Workshop on New Approaches to Liquefaction, Publication No. FHWARD-99-165, Federal Highway Administration.

IDRISS, I.M. \& BOULANGER, R.W. (2006): Semi-empirical procedures for evaluating liquefaction potential during earthquakes.- Soil Dyn. Earthq. Eng., 26, 115-130. doi: 10.1016/j.soildyn.2004.11.023

IDRISS, I.M. \& BOULANGER, R.W. (2010): SPT based liquefaction triggering procedures. Report No. UCD/CGM-10-02. Center for Geotechnical Modeling, Department of Civil and Environmental Engineering, University of California. Davis, California.

ISHIHARA, K., TRONCOSO, J., KAWASE, Y. \& TAKAHASHI, Y. (1980): Cyclic strength characteristics of tailings materials.- Soils and Foundations, 20/4, 127-142. doi: 10.3208/sandf1972.20.4_127

KRAMER, S.L. (1996): Geotechnical Earthquake Engineering. Prentice Hall.

LAI, C.G., MEISINA, C., COSENTINI R. M., BOZZONI, F., PERSICHILLO, P., BORDONI, M., TUMIATI, M., VIANA DA FONSECA, A., FERREIRA, C., RAMOS, C., PETKOVŠEK, A., SMOLAR, J., OBLAK, A., MAČEK, M., KOSIČ, M., KUDER, S., PETROVIČ, D., DOLŠEK, M., LESJAK, M., ZAKONJŠEK, D., LESJAK, I., STRNIŠA, G., PADOVAN, B., LOGAR, J., OZCEP, F., OZTOPRAK, S., BOZBEY, I., AYSAL, N., OSER, C., SARGIN, S., TEZEL, O., CINKU, M. \& OZDEMIR, K. (2017): Report on ground characterization of the four areas selected as testing sites by using novel technique and advances metodologies to perform in situ and laboratory tests. Deliverable D2.1. V 1.0. Project Liquefact, H2020-DRA-2015, GA no. 700748

MARCHETTI, D. \& MARCHETTI, S. (2016): Flat Dilatometer (DMT). Some Recent Advances.- Procedia Eng., 158, 428-433. doi: 10.1016/j.proeng.2016.08.467

PETKOVŠEK, A., MAČEK, M. \& SMOLAR, J. (2017): Testing methods for mechanically improved soils: RELIABILITY AND VALIDITY.-Acta Polytech. CTU Proc. 10, 16-33. doi: 10.14311/APP.2017.10.0016

POLITO, C.P. \& MARTIN, J.R. (2001): Effects of Nonplastic Fines on the Liquefaction Resistance of Sands.- J. Geotech. Geoenvironmental Eng., 127, 408-415. doi: 10.1061/(ASCE)1090-0241(2001)127:5(408)

ROBERTSON, P.K. (2012): Interpretation of in-situ tests - some insights.- In: Proc. 4 Int. Conf. on Site Characterization. Presented at the ISC'4, Brazil.

ROLLINS, K.M. \& REMUND, T.K. (2016): Evaluation of DMT liquefaction triggering curves based on field case histories.- In: Geotechnical and Geophysical Site Characterization 5. Sydney.
SHENGCONG, F. \& TATSUOKA, F. (1984): Soil liquefaction during Haicheng and Tangshan Earthquake in China.-A review. SOILS Found. 24, 11-29. doi: 10.3208/ sandf1972.24.4_11.

SIST EN ISO 22476-3 (2005): Geotechnical investigation and testing - Field testing Part 3: Standard penetration test (ISO 22476-3:2005).

SIST EN ISO 22476-1 (2013): Geotechnical investigation and testing - Field testing Part 1: Electrical cone and piezocone penetration test (ISO 22476-1:2012).

SIST-TS CEN ISO/TS 17892-1 (2004): Geotechnical investigation and testing - Laboratory testing of soil - Part 1: Determination of water content (ISO 17892-1:2014).

SIST-TS CEN ISO/TS 17892-2 (2004): Geotechnical investigation and testing - Laboratory testing of soil - Part 2: Determination of bulk density (ISO/TS 17892-2:2004).

SIST-TS CEN ISO/TS 17892-3 (2004): Geotechnical investigation and testing - Laboratory testing of soil - Part 3: Determination of particle density - Pycnometer method (ISO/TS 17892-3:2004).

SIST-TS CEN ISO/TS 17892-4 (2004): Geotechnical investigation and testing - Laboratory testing of soil - Part 4: Determination of particle size distribution (ISO/TS 17892-4:2004)

SIST-TS CEN ISO/TS 17892-12 (2004): Geotechnical investigation and testing - Laboratory testing of soil - Part 12: Determination of Atterberg limits (ISO/TS 1789212:2004).

SIST-TS CEN ISO/TS 22476-11 (2008): Geotechnical investigation and testing - Field testing - Part 11: Flat dilatometer test (ISO 22476-11:2005).

VEINOVIĆ, Ž., DOMITROVIĆ, D. \& LOVRIĆ, T. (2007): Pojava likvefakcije na području Zagreba u prošlosti i procjena mogićnosti ponovne pojave tjekom jačeg potresa.- Rud.-Geol.-Naft. Zb., 19, 111-120.

VUKADIN, V. (2013): The improvement of the loosely deposited sands and silts with the Rapid Impact Compaction technique on Brežice test sites.- Engineering Geology, 160, 69-80. doi: 10.1016/j.enggeo.2013.03.025

YOUD, T.L., IDRISS, I.M., ANDRUS, R.D., ARANGO, I., CASTRO, G., CHRISTIAN, J.T., DOBRY, R., FINN, W.D.L., HARDER, L.F., HYNES, M.E., ISHIHARA, K., KOESTER, J.P., LIAO, S.S.C., MARCUSON, W.F., MARTIN, G.R., MITCHELL, J.K., MORIWAKI, Y., POWER, M.S., ROBERTSON, P.K., SEED, R.B. \& STOKOE, K.H. (2001): Liquefaction Resistance of Soils: Summary Report from the 1996 NCEER and 1998 NCEER/NSF Workshops on Evaluation of Liquefaction Resistance of Soils.- J. Geotech. Geoenvironmental Eng., 127, 817-833. doi: 10.1061/(ASCE)1090-0241(2001)127:10(817) 